\title{
Small-Subunit rRNA Sequences and Whole DNA Relatedness Concur for the Reassignment of Pasteurella piscicida (Snieszko et al.) Janssen and Surgalla to the Genus Photobacterium as Photobacterium damsela subsp. piscicida comb. nov.

\author{
G. GAUTHIER, ${ }^{1}$ B. LAFAY, ${ }^{1}$ R. RUIMY, ${ }^{1}$ V. BREITTMAYER,${ }^{2}$ J. L. NICOLAS,${ }^{3}$ M. GAUTHIER, ${ }^{2}$ \\ AND R. CHRISTEN ${ }^{1 *}$
}

Centre National de la Recherche Scientifique and Université Paris 6, Station Zoologique, Villefranche sur mer 06230, ${ }^{1}$ Institut National de la Santé et de la Recherche Médicale U 303, CERBOM, Nice 06300, ${ }^{2}$ and IFREMER, Centre de Brest, Plouzané $29280,{ }^{3}$ France

\begin{abstract}
The taxonomic status of Pasteurella piscicida (strain NCIMB 2058 T $[\mathrm{T}=$ type strain] and a strain isolated from the environment) was investigated by performing phylogenetic analyses of small-subunit rRNA sequences, DNA-DNA hybridization analyses, and biochemical characterization analyses. The results of the phylogenetic analyses and the levels of DNA-DNA complementarity demonstrated conclusively that Pasteurella piscicida is extremely closely related to Photobacterium damsela ATCC $33539^{\mathrm{T}}$. Since the two taxa exhibited a level of DNA-DNA relatedness of $80 \%$, they are members of the same species. The high level of DNA relatedness and the presence of specific morphological and biochemical characteristics support the hypothesis that two subspecies should be recognized. On the basis of its phylogenetic position, we concluded that Pasteurella piscicida should be renamed Photobacterium damsela subsp. piscicida comb. nov.
\end{abstract}

In 1963, an epizootic destroyed $50 \%$ of the white perch (Roccus americanus) and striped bass (Roccus saxatilis) in the upper Chesapeake Bay. The bacteria responsible for this fish disease were quickly isolated (24) and were later shown to cause considerable losses in marine aquaculture environments (reviewed in reference 15). These bacteria, which are not present in healthy fish, cause infection and death when they are inoculated into fish (1). Virulence seems to be caused by a thermolabile phospholipase (16), which has also been found in other fish pathogens, including Aeromonas salmonicida (14) and Photobacterium damsela (13).

On the basis of its general physiology (gram-negative cells that are non-motile, oxidase positive, and rod shaped and exhibit bipolar staining), the bacterium that was responsible for the epizootic was first placed in the genus Pasteurella, without a specific designation (24). The name Pasteurella piscicida was later proposed (11) despite the inability of the organism to reduce nitrate and its tolerance of $\mathrm{pH}$ values and temperatures that were unusual for members of the genus Pasteurella and despite the fact that it was the only marine representative of the genus. A later general analysis led to the conclusion that Pasteurella piscicida might be closely related to the genus Vibrio, but characteristics such as the lack of motility, variable Gram staining reactions, and changing from rods to coccoids were thought to be incompatible with this genus and led to an alternative suggestion that the genus Arthrobacter would be a more suitable genus for this organism (21). Finally, on the basis of rRNA cistrons similarity data, Pasteurella piscicida appeared to be a member of the family Vibrionaceae (7). Probably because of the uncertainty concerning the correct position of the organism, the name Pasteurella piscicida did not appear on the Approved Lists of Bacterial Names (22).

Interest in this bacterium increased in 1990 when it affected many different marine fish in Europe. A comparison of strains

\footnotetext{
* Corresponding author. Phone: (33) 937637 80. Fax: (33) 937638 93. Electronic mail address: christen@ccrv.obs-vlfr.fr.
}

isolated from the coasts of Europe with strains obtained from Japan and North America showed that these organisms formed a phenotypically, serologically, and genetically homogeneous taxon (15). In the meantime, molecular probes were characterized in order to rapidly identify Pasteurella piscicida and to try to prevent spread of the disease $(29,30)$. In these studies the workers examined probe specificity only with what were thought to be related species (i.e., mostly other Pasteurella species) $(29,30)$. Therefore, it is important that the taxonomic status of Pasteurella piscicida be determined with precision, particularly if this bacterium in fact does not belong to the genus Pasteurella.

While we were working on a field study of fish pathogens, a bacterium isolated from the environment was identified as Pasteurella piscicida by classical methods, but as a member of the family Vibrionaceae by small-subunit rRNA sequence analysis. To resolve this inconsistency, we also obtained and analyzed a Pasteurella piscicida reference strain. In our study we performed a phylogenetic analysis of the small-subunit rRNA sequences of both strains, a DNA-DNA hybridization analysis, and a biochemical characterization analysis. We found that bacteria formerly known as Pasteurella piscicida are indeed members of the family Vibrionaceae (19) and that their levels of genetic relatedness to Photobacterium damsela should lead to a change in the taxonomic status of these organisms.

\section{MATERIALS AND METHODS}

Bacterial strains and bacteriological media. The wild strain of Pasteurella piscicida used in this study was isolated from sea bass (Dicentrarchus labrax) obtained from the Mediterranean Sea by workers at the Centre National d'Etudes Vétérinaire et Alimentaires, Laboratoire de Pathologie des Animaux Aquatiques, Biot, France. Reference strain Pasteurella piscicida NCIMB $2058^{\mathrm{T}}$ ( $\mathrm{T}=$ type strain) was obtained directly from the National Collection of Industrial and Marine Bacteria, Aberdeen, Scotland. These two strains were grown at $22^{\circ} \mathrm{C}$ on brain heart infusion agar (Difco Laboratories, Detroit, Mich.) supplemented with $0.3 \mathrm{M} \mathrm{NaCl}$ or were stored frozen at $-70^{\circ} \mathrm{C}$ in brain heart infusion broth containing $20 \%$ (vol $/ \mathrm{vol}$ ) glycerol.

Photobacterium damsela ATCC $33539^{\mathrm{T}}$ was obtained directly from the American Type Culture Collection, Rockville, Md. This strain was maintained at $22^{\circ} \mathrm{C}$ 
on marine agar 2216 (Difco) or was stored frozen at $-70^{\circ} \mathrm{C}$ in marine broth containing $20 \%$ (vol/vol) glycerol.

Phenotypic characterization. Most of the methods used to characterize Pasteurella piscicida and Photobacterium damsela have been described previously (3-5). The exceptions were the tests performed with API 20E, API 20NE, and API 50CH galleries (API-System; Biomerieux, Marcy l'Etoile, France); in these tests the preparations were supplemented with $0.3 \mathrm{M} \mathrm{NaCl}$ and incubated at $22^{\circ} \mathrm{C}$. The flagellation of Pasteurella piscicida was assessed by transmission electron microscopy, using cells grown in $0.25 \times$ and $1 \times$ marine broth (Difco) and collected at the mid-exponential and late stationary phases of growth. The cells were negatively stained with phosphotungstic acid by using the method of Jahn (10) and were observed with a Philips model CM2 transmission electron microscope operating at $100 \mathrm{kV}$.

Assimilation of carbohydrates was verified as described by Janssen and Surgalla (11), and susceptibility to antibiotics was determined as described by Gauthier and Breittmayer (9). The ability to accumulate poly- $\beta$-hydroxybutyrate (PHB) as an extracellular reserve product was determined by using the media described by Reichelt and Baumann (18); cells were examined for the presence of PHB granules by phase-contrast microscopy. Whether an organism accumulated PHB was also determined by spectrophotometry (26) by using cells grown under nitrogen-limiting conditions with glucose as the sole source of carbon and energy.

DNA amplification. The method used to prepare bacterial DNA for PCR was derived from the method of Sritharan and Barker (25). Bacteria were grown on marine agar and then were suspended in $200 \mu$ l of a lysis solution $(10 \mathrm{mM}$ Tris [pH 8.0], $1 \mathrm{mM}$ EDTA, 1\% Triton X-100) and boiled for $5 \mathrm{~min}$. Following a single chloroform extraction, $5 \mu$ of supernatant was used to amplify smallsubunit rRNA genes. To do this, we used two primers, which corresponded to positions 8 to 28 and 1498 to 1509 of the Escherichia coli small-subunit rRNA sequence. An initial denaturation step was performed at $95^{\circ} \mathrm{C}$ for $180 \mathrm{~s}$; this was followed by annealing at $52^{\circ} \mathrm{C}$ for $60 \mathrm{~s}$ and extension at $72^{\circ} \mathrm{C}$ for $90 \mathrm{~s}$. The preparation was then subjected to 25 cycles consisting of denaturation at $94^{\circ} \mathrm{C}$ for $30 \mathrm{~s}$, annealing at $52^{\circ} \mathrm{C}$ for $60 \mathrm{~s}$, and extension at $72^{\circ} \mathrm{C}$ for $90 \mathrm{~s}$. A final extension step was performed at $72^{\circ} \mathrm{C}$ for $5 \mathrm{~min}$. This amplification procedure produced 1.5-kb DNA molecules.

Direct sequencing of PCR products. After purification on a $1 \%$ low-meltingpoint agarose gel, PCR products were sequenced directly as described previously (19).

Phylogenetic analysis. Small-subunit rRNA sequences were aligned and examined by using a set of programs developed in our laboratory (available from R. Christen). The sequence domains used for the phylogenetic analyses (Fig. 1) were the following conserved regions of the small-subunit rRNA sequences: positions 42 to 74,93 to 453,473 to 836,849 to 1004,1023 to 1130 , and 1137 to 1426 (Escherichia coli small-subunit rRNA sequence numbering).

Phylogenetic analyses were performed by using three different methods. A neighbor-joining method (20) was used in a preliminary analysis. The resulting topologies were then further investigated by performing maximum-likelihood and maximum-parsimony analyses. For the maximum-likelihood analyses we used the fdnaml program rewritten by G. J. Olsen (University of Illinois, Urbana) and compiled on a Hewlett-Packard model 700 workstation, while the maximumparsimony analyses were performed with the PAUP program for Macintosh computers (27). In the latter case, the analyses were performed by using the branch-and-bound option or the heuristic option when the branch-and-bound option was too time-consuming. The robustness of each topology was evaluated by performing a maximum-parsimony analysis through 100 bootstrap replications (heuristic search). Trees were drawn by using the njplot program for Macintosh computers developed by M. Gouy (Université Claude Bernard, Lyon, France), which allows transformation of a formal tree representation (Newick's format) into "MacDraw" drawings.

DNA-DNA hybridization. DNA was prepared by a procedure adapted from the procedure of Marmur (17). Bacteria were incubated overnight at $25^{\circ} \mathrm{C}$ with shaking. Cells were collected by centrifugation at $13,000 \times g$ for $20 \mathrm{~min}$ and then resuspended in saline-EDTA buffer (0.1 M EDTA, $0.15 \mathrm{M} \mathrm{NaCl}[\mathrm{pH} 8])$ containing $1.4 \%$ sodium dodecyl sulfate. After $5 \mathrm{~min}$ of incubation at $60^{\circ} \mathrm{C}$, sodium perchlorate (final concentration, $0.8 \mathrm{M}$ ) and an equal volume of a chloroform-isoamyl alcohol solution $(24: 1, \mathrm{vol} / \mathrm{vol})$ were added. The mixture was shaken for $10 \mathrm{~min}$ and then centrifuged at $4,300 \times \mathrm{g}$ for $20 \mathrm{~min}$. Then 2 volumes of cold $\left(-20^{\circ} \mathrm{C}\right)$ ethanol was slowly added to the upper aqueous phase, and the resulting precipitate was collected, resuspended, and digested with RNAse (final concentration, $0.6 \mathrm{U} / \mathrm{ml}$ ) at $37^{\circ} \mathrm{C}$ for $30 \mathrm{~min}$. Following two chloroform-isoamyl alcohol extractions, the DNA was precipitated with ethanol and resuspended in $10 \mathrm{ml}$ of $1 \times \mathrm{SSC}(1 \times \mathrm{SSC}$ is $150 \mathrm{mM} \mathrm{NaCl}$ plus $15 \mathrm{mM}$ sodium citrate, $\mathrm{pH} 7.0)$; then 0.5 volume of 2 -propanol was added drop by drop with slow shaking. The resulting precipitate was washed with $70 \%$ ethanol, dried, and dissolved in $0.1 \times$ SSC. Absorbance ratios $\left(A_{280}, A_{260}\right.$, and $\left.\mathrm{A}_{230}\right)$ were used to assess the purity of each DNA preparation. After repeated shearing caused by passage through a 27-gauge needle, the extent of DNA reassociation was determined spectrophotometrically in $1 \times$ SSC containing $20 \%$ dimethyl sulfoxide. The incubation time was approximately $3 \mathrm{~h}$, and the final DNA concentration was adjusted to 75 $\mu \mathrm{g} / \mathrm{ml}\left(\boldsymbol{A}_{260}, 1.5\right)$. Experiments were performed in a six-place cuvette holder; the cuvettes contained a blank, DNA from each strain used, and mixtures of DNAs (Pasteurella piscicida NCIMB $2058^{\mathrm{T}}$ DNA plus wild-type DNA and Pasteurella piscicida NCIMB 2058 ${ }^{\mathrm{T}}$ DNA plus Photobacterium damsela ATCC $33539^{\mathrm{T}}$ DNA). The experiments were performed in a Gilford apparatus. Levels of DNA reassociation were calculated as described by De Ley et al. (6).

Nucleotide sequence accession numbers. The EMBL accession numbers for the small-subunit rRNA sequences of the bacteria which we analyzed (Fig. 1) are as follows: Vibrio anguillarum, X16895; Vibrio carchariae, X74693; Vibrio hollisae X74707; Vibrio logei, X74708; Vibrio natriegens, X74714; Vibrio nereis, X74716; Photobacterium damsela, X74700; Photobacterium angustum, X74685; Photobacterium leiognathi, X74868; Photobacterium phosphoreum, X74687; Actinobacillus hominis, L06076; Actinobacillus lignieresii, M35017; Haemophilus aphrophilus, M75041; Haemophilus ducreyi, M63900; Haemophilus influenzae, M35019; Pasteurella aerogenes, M75048; Pasteurella avium, M75058; Pasteurella multocida, M35018; Aeromonas caviae, X74674; Aeromonas eucrenophila, X74675; Aeromonas jandaei, X74678; Citrobacter freundii, M59291; Erwinia carotovora, M59149; Escherichia coli, J01859; Hafnia alvei, M59155; Plesiomonas shigelloides, M59159; Proteus vulgaris, X07652; Serratia marcescens, M59160; and Yersinia enterocolitica, M59292. The small-subunit rRNA sequences of Pasteurella piscicida NCIMB $2058^{\mathrm{T}}$ and the wild isolate of Pasteurella piscicida have been deposited in the EMBL data bank under accession numbers X78105 and X78106, respectively. The small-subunit rRNA sequences for Vibrio and Photobacterium strains determined in our laboratory are available from the EMBL data bank under accession numbers $\mathrm{X} 74674$ to $\mathrm{X} 74727$.

\section{RESULTS}

Small-subunit rRNA sequences and phylogenetic analysis. The small-subunit rRNA sequences of strain NCIMB $2058^{\mathrm{T}}$ and the wild strain of Pasteurella piscicida were identical. Because of this, all phylogenetic analyses were performed with a single Pasteurella piscicida small-subunit rRNA sequence. Most small-subunit rRNA sequences for Vibrio and Photobacterium strains have been determined in our laboratory (19). All sequences were aligned by comparing them with the sequences in a database containing more than 1,800 aligned eubacterial small-subunit rRNA sequences.

The results of phylogenetic analyses in which we used representatives of all eubacterial phyla and all subdivisions of the Proteobacteria confirmed that Pasteurella piscicida belonged to a well-defined taxon which is known as the gamma-3 subgroup of the phylum Proteobacteria. This taxon includes the families Enterobacteriaceae, Aeromonadaceae, Pasteurellaceae, and Vibrionaceae $(19,28)$. The phylogenetic position of Pasteurella piscicida was then investigated in more detail by using only representatives of these four families. The analyses were performed by using three phylogenetic methods: the neighborjoining method, the maximum-parsimony method, and the maximum-likelihood method. The phylogenetic positions of the bacteria which we investigated were always the same, regardless of which method was used or which outgroups were chosen (results are summarized in Fig. 1). Pasteurella piscicida and Photobacterium damsela always formed a monophyletic taxon (as determined by all methods; $100 \%$ of bootstrap replications). A detailed analysis of Fig. 1 revealed that when we used the maximum-parsimony method and the heuristic search option, we obtained two equally most-parsimonious trees (length, 847; consistency index, 0.466; retention index, 0.761) that differed only in the positions of Haemophilus aphrophilus and Haemophilus ducreyi. Because the branch-andbound approach was too time-consuming when the whole set of data was used, this analysis was performed with a reduced set of data (data for 15 taxa representating the four families which we studied). In this analysis we obtained eight equally most-parsimonious trees (length, 492; consistency index, 0.644; retention index, 0.773 ), all of which confirmed the placement of Pasteurella piscicida in the Vibrionaceae and the association of this organism with Photobacterium damsela; these results completely agreed with the results obtained when we used the neighbor-joining and maximum-likelihood methods. The robustness of the data was also demonstrated by the support of $100 \%$ of the bootstrap replications. A direct analysis of DNA 


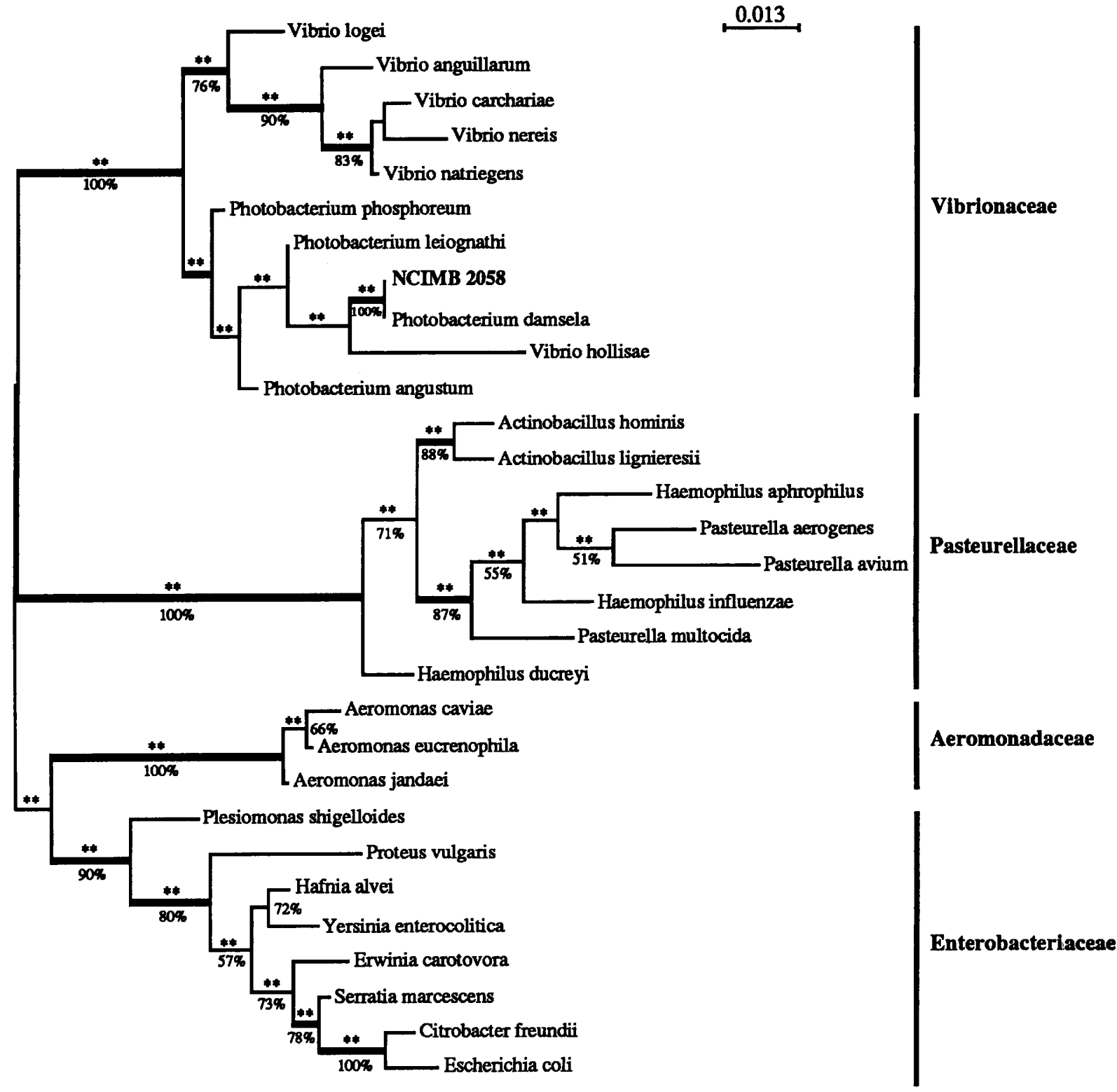

FIG. 1. Phylogenetic position of strain NCIMB $2058^{\mathrm{T}}$ : unrooted tree showing the results of a phylogenetic analysis of the small-subunit rRNA sequences of strain NCIMB $2058^{\mathrm{T}}$ and related bacteria. The topology was obtained by using a maximum-likelihood method; the branches that are significantly positive at $P<0.01$ are indicated by double asterisks. The thick lines indicate monophyletic taxa that were also found when a neighbor-joining analysis was performed. The same topology was obtained when a maximum-parsimony method was used, and the percentages corresponding to the values from a bootstrap analysis when the maximum-parsimony method was used are indicated under the branches.

sequences revealed that the rRNA sequences of Pasteurella piscicida and Photobacterium damsela differed by only one nucleotide among the 1,434 positions sequenced (the nucleotides at one position for Pasteurella piscicida and two positions for Photobacterium damsela remained undetermined).

Morphological and biochemical description of Pasteurella piscicida. (i) Morphology. The two strains of Pasteurella piscicida which we studied were facultatively anaerobic, gramnegative, straight rods which exhibited bipolar staining, and neither of the strains was bioluminescent. Neither strain produced flagella under the cultural conditions used in this study.

(ii) Growth, halotolerance, and $\mathrm{Na}^{+}$requirement. The wild Pasteurella piscicida isolate grew in ordinary media supple- mented with 0.1 to $0.5 \mathrm{M} \mathrm{NaCl}$, and strain $\mathrm{NCIMB} 2058^{\mathrm{T}}$ grew in ordinary media containing 0.2 to $0.5 \mathrm{M} \mathrm{NaCl}$; optimal growth occurred in the presence of $0.3 \mathrm{M} \mathrm{NaCl}$. Both strains exhibited an absolute requirement for $\mathrm{Na}^{+}$since they did not grow in the presence of $\mathrm{Na}^{+}$concentrations lower than $2 \times$ $10^{-2} \mathrm{M}$. Growth was optimal in brain heart infusion medium containing $0.3 \mathrm{M} \mathrm{NaCl}$, and the osmotic requirements ranged from 0.5 to $3 \% \mathrm{NaCl}$. Pasteurella piscicida grew in appropriate media at 25 and $35^{\circ} \mathrm{C}$ but not at 4 and $37^{\circ} \mathrm{C}$, and at initial pH values of 6 to 9 . The two strains accumulated the storage product PHB when they were grown on medium containing glucose, but they were not able to utilize the exogenous monomer DL- $\beta$-hydroxybutyrate.

(iii) Biochemical characterization. The two Pasteurella pis- 
cicida strains used glucose, mannose, glutamate, adipate, Lproline, and $N$-acetylglucosamine as sole carbon sources but did not use xylose, cellobiose, gluconate, acetate, pyruvate, and $\beta$-hydroxybutyrate. Glucose, fructose, and mannose were fermented anaerobically by these organisms; galactose, sucrose, and raffinose were weakly fermented; and L-arabinose, Dmannitol, L-rhamnose, D-glucitol, trehalose, D-xylose, maltose, melibiose, lactose, cellobiose, glycerol, and galactitol were not fermented. Oxidase, catalase, phospholipase, arginine decarboxylase, lecithinase, tweenase 80 , tweenase 20 , and DNAse tests were positive; and urease, nitrate reductase, agarase, and alginase tests were negative. Gelatin was not liquified, and indole was not produced. The two strains differed only in their ability to hydrolyze starch (the amylase test was negative for strain NCIMB $2058^{\mathrm{T}}$ ).

(iv) Susceptibility to antibiotics. Both strains of Pasteurella piscicida were susceptible to chloramphenicol and tetracycline on marine agar and to the vibriostatic agent pteridin $\mathrm{O} / 129$ and novobiocin on Mueller-Hinton medium. They were moderately susceptible to neomycin and gentamicin and resistant to streptomycin, kanamycin, and erythromycin on marine agar.

Description of Photobacterium damsela. We also examined the characteristics described above for Photobacterium damsela. Photobacterium damsela differed from Pasteurella piscicida in the following ways: Photobacterium damsela was flagellated and grew at $37^{\circ} \mathrm{C}$ and at $\mathrm{pH}$ values of 5 to 10 ; the urease and nitrate reductase tests were positive; the lecithinase and phospholipase tests were negative; starch was hydrolyzed; maltose, cellobiose, acetate, and pyruvate were assimilated; and maltose and cellobiose were fermented.

Accumulation of PHB. The results of the two methods used to study accumulation of PHB (microscopy and spectrophotometry) demonstrated that PHB was accumulated as an intracellular reserve product by Photobacterium damsela, Pasteurella piscicida, Photobacterium leiognathi, and $V$. hollisae ATCC $33564^{\mathrm{T}}$. Only the spectrophotometric method proved without a doubt that Vibrio costicola ATCC $33508^{\mathrm{T}}$ accumulated PHB (detection of PHB granules by phase-contrast microscopy was not feasible). $V$. logei and Vibrio fisheri did not accumulate PHB.

DNA-DNA hybridization. Our DNA-DNA hybridization analysis revealed that there was a high level of DNA-DNA relatedness (95\%) between the two strains of Pasteurella piscicida tested, which confirmed that they belong to the same species. A level of relatedness of $80 \%$ confirmed that Pasteurella piscicida and Photobacterium damsela belong to the same bacterial species.

\section{DISCUSSION}

Our small-subunit rRNA sequence analyses revealed unambiguously that Pasteurella piscicida should be affiliated with the family Vibrionaceae, which is consistent with data from previous rRNA cistron similarity studies (7). More precisely, all of the phylogenetic methods used (neighbor joining, maximum likelihood, maximum parsimony) revealed that the relationship between Pasteurella piscicida and Photobacterium damsela is monophyletic. However, two bacteria can be considered members of the same species only when they exhibit a level of genomic DNA relatedness of more than $70 \%$ (12). Since the level of complementarity of the DNAs of Pasteurella piscicida NCIMB $2058^{\mathrm{T}}$ and Photobacterium damsela ATCC $33539^{\mathrm{T}}$ was $80 \%$, it is appropriate to consider these organisms members of a single species.

The criteria used to discriminate one subspecies from another differ according to the genus (12). Morphological and biochemical analyses revealed a number of important traits such as the presence of a flagellum and urease and nitrate reductase activities, which could be used to differentiate the organisms which we studied. Thus, strains ATCC $33539^{\mathrm{T}}$ and NCIMB $2058^{\mathrm{T}}$ are different enough to be considered members of different subspecies. Because these strains belong to the family Vibrionaceae, the generic name Pasteurella cannot be retained. Thus, it is appropriate to reject the name Pasteurella piscicida and to rename strain NCIMB 2058 ${ }^{\mathrm{T}}$ Photobacterium damsela subsp. piscicida comb. nov.; Photobacterium damsela should be renamed Photobacterium damsela subsp. damsela comb. nov. (type strain, ATCC 33539).

Table 1 summarizes the main phenotypic traits that differentiate Photobacterium species and subspecies, including the two Photobacterium damsela subspecies. All Photobacterium spp. are able to accumulate $\mathrm{PHB}$ as an extracellular reserve product, a property that was of considerable taxonomic importance in the definition of the genus Photobacterium (2). On the basis of their ability to grow at either a low temperature $\left(4^{\circ} \mathrm{C}\right)$ or a high temperature $\left(35^{\circ} \mathrm{C}\right)$, these bacteria could be divided into a psychrotolerant group (Photobacterium phosphoreum, Photobacterium angustum) and a thermotolerant group (Photobacterium leiognathi, Photobacterium damsela subsp. damsela, Photobacterium damsela subsp. piscicida). Photobacterium damsela subsp. piscicida is the only nonflagellated member of the genus Photobacterium.

In a previous phylogenetic analysis based on nearly complete small-subunit rRNA sequences, Ruimy et al. (19) showed that the family Vibrionaceae can be divided into the following three monophyletic groups: (i) V. logei and V. fisheri; (ii) all Photobacterium species plus $V$. hollisae and $V$. costicola; and (iii) all remaining Vibrio species. On the basis of phylogenetic analysis results and results of $\mathrm{PHB}$ accumulation analyses, reassignment of $V$. hollisae and $V$. costicola to the genus of Photobacterium should now be considered.

In terms of morphology, it is interesting that the presence of a flagellar structure is an important characteristic that can be used to distinguish the two subspecies of Photobacterium damsela. The variability observed in this species weakens the meaning of this structural trait for taxonomic purposes. It also suggests that the presence of flagella could be a rather versatile characteristic and that loss of flagella may result from divergent evolution even in very closely related bacteria. In terms of genetics, we observed one difference between the rRNA sequences of the two subspecies which we investigated. The correlation among species identification, rRNA sequences, and levels of DNA-DNA hybridization has been discussed previously (8), and it is now clear that (i) phylogenetic analysis of rRNA sequences is now the fastest method to determine to which bacterial species a new strain is most closely related, (ii) there is at the present time no reason to believe that a strict relationship should be found for all genera regarding the number of differences observed in the rRNA sequences of two bacteria and their genetic relatedness when the entire genome is considered, and (iii) there is probably no unique criterion for defining a bacterial species, since the definition of a bacterial species is related to its ecophysiology as much as it is to its genetic composition.

Amended description of Photobacterium damsela subsp. piscicida (Snieszko et al. 1964) Gauthier, Lafay, Breittmayer, Ruimy, Nicolas, Gauthier, and Christen comb. nov. Photobacterium damsela subsp. piscicida (L. n. piscis, a fish; L. suff. -cida, from L. v. caedo, to cut or to kill; M.L. n. piscicida, fish killer). Cells are gram-negative, nonflagellated, straight rods which exhibit bipolar staining. Facultatively anaerobic. Accumulates the storage product PHB when cells are grown on medium 
TABLE 1. Characteristics that differentiate Photobacterium damsela subsp. piscicida from other Photobacterium species and subspecies

\begin{tabular}{|c|c|c|c|c|c|}
\hline Characteristic & $\begin{array}{l}\text { Photobacterium } \\
\text { damsela subsp. } \\
\quad \text { piscicida }\end{array}$ & $\begin{array}{l}\text { Photobacterium } \\
\text { damsela subsp. } \\
\qquad \text { damsela }\end{array}$ & $\begin{array}{l}\text { Photobacterium } \\
\text { leiognathi }^{b}\end{array}$ & $\begin{array}{l}\text { Photobacterium } \\
\text { angustrum }^{b}\end{array}$ & $\begin{array}{l}\text { Photobacterium } \\
\text { phosphoreum }^{b}\end{array}$ \\
\hline Flagella & $-^{c}$ & + & + & + & + \\
\hline Bioluminescence & - & - & + & - & + \\
\hline \multicolumn{6}{|l|}{ Growth at: } \\
\hline $4^{\circ} \mathrm{C}$ & - & - & - & + & + \\
\hline $35^{\circ} \mathrm{C}$ & + & + & + & - & - \\
\hline Nitrate reductase & - & + & + & $\mathrm{d}$ & + \\
\hline Lipase & - & + & + & $\mathrm{d}$ & - \\
\hline Phospholipase & + & - & ND & ND & ND \\
\hline Gelatinase & - & - & - & + & - \\
\hline Esculinase & - & + & ND & ND & ND \\
\hline Urease & - & + & ND & ND & ND \\
\hline \multicolumn{6}{|l|}{ Utilization of: } \\
\hline D-Xylose & - & ND & - & + & - \\
\hline Maltose & - & + & - & d & + \\
\hline Cellobiose & - & + & - & - & - \\
\hline Gluconate & - & - & + & + & + \\
\hline DL-Glycerate & ND & + & d & - & + \\
\hline Glutamate & + & + & d & - & $\mathrm{d}$ \\
\hline Acetate & - & + & + & d & - \\
\hline Pyruvate & - & + & + & + & - \\
\hline Adipate & + & + & - & - & - \\
\hline L-Proline & + & ND & + & - & - \\
\hline
\end{tabular}

${ }^{a}$ Data from reference 23 and this study.

${ }^{b}$ Data from reference 3 .

$c_{-}$, negative; +, positive; d, variable; ND, not determined.

containing glucose, but does not utilize the exogenous monomer DL- $\beta$-hydroxybutyrate. Oxidase, catalase, phospholipase, and lecithinase positive. Urease and nitrate reductase negative. No growth occurs in the absence of sodium ions. Not bioluminescent. Does not produce extracellular gelatinase, agarase, and alginase. The following carbon compounds are utilized as sole carbon and energy sources: glucose, mannose, glutamate, adipate, L-proline, and $N$-acetylglucosamine. Glucose, fructose, mannose, galactose, sucrose, and raffinose are fermented anaerobically. L-Arabinose, D-mannitol, L-rhamnose, D-glucitol, trehalose, D-xylose, maltose, melibiose, lactose, glycerol, galactitol, and cellobiose are not fermented. Isolated from diseased fish. The type strain is NCIMB 2058.

\section{REFERENCES}

1. Allen, N., and M. J. Pelzcar. 1967. Bacteriological studies on the white perch, Roccus americanus. Chesapeake Sci. 8:135-154.

2. Baumann, P., and L. Baumann. 1981. The marine Gram-negative eubacteria: genera Photobacterium, Beneckea, Alteromonas, Pseudomonas, and Alcaligenes, p. 1302-1331. In M. P. Starr, H. Stolp, H. G. Trüper, A. Balows, and H. G. Schlegel (ed.), The prokaryotes. Springer-Verlag, Berlin.

3. Baumann, P., and L. Baumann. 1984. Genus II. Photobacterium Beijerinck 1889, p. 539-545. In N. R. Kreig and J. G. Holt (ed.), Bergey's manual of systematic bacteriology, vol. 1. The Williams \& Wilkins Co., Baltimore.

4. Baumann, P., A. L. Furniss, and J. V. Lee. 1984. Genus I. Vibrio Pacini 1854, p. 518-538. In N. R. Kreig and J. G. Holt (ed.), Bergey's manual of systematic bacteriology, vol. 1. The Williams \& Wilkins Co., Baltimore.

5. Baumann, P., and R. H. W. Schubert. 1984. Family II. Vibrionaceae Veron 1965, p. 516-517. In N. R. Kreig and J. G. Holt (ed.), Bergey's manual of systematic bacteriology, vol. 1. The Williams \& Wilkins Co., Baltimore.

6. De Ley, J., H. Cattoir, and A. Reynaerts. 1970. The quantitative measurement of DNA hybridization from renaturation rates. Eur. J. Biochem. 12:133-142.

7. De Ley, J., W. Mannheim, R. Mutters, K. Piechulla, R. Tytgat, P. Segers, M. Bisgaard, W. Frederiksen, K.-H. Hinz, and M. Vanhoucke. 1990. Inter- and intrafamilial similarities of rRNA cistrons of the Pasteurellaceae. Int. J. Syst. Bacteriol. 40:126-137.

8. Fox, G. E., J. D. Wisotzkey, and P. Jurtshuk. 1992. How close is close: 16S rRNA sequence identity may not be sufficient to guarantee species identity. Int. J. Syst. Bacteriol. 42:166-170.

9. Gauthier, M. J., and V. A. Breittmayer. 1979. A new antibiotic-producing bacterium from seawater: Alteromonas aurantia sp. nov. Int. J. Syst. Bacte- riol. 29:366-372.

10. Jahn, K. 1986. Isolation and characterization of fimbriae from Escherichia coli, p. 381-388. In M. Sussman (ed.), The virulence of Escherichia coli. Reviews and methods. Academic Press, London.

11. Janssen, W. A., and M. J. Surgalla. 1968. Morphology, physiology, and serology of a Pasteurella species pathogenic for white perch (Roccus americanus). J. Bacteriol. 96:1606-1610.

12. Johnson, J. L. 1984. Bacterial classification. III. Nucleic acids in bacterial classification, p. 8-11. In N. R. Krieg and J. G. Holt (ed.), Bergey's manual of systematic bacteriology, vol. 1. The Williams \& Wilkins Co., Baltimore.

13. Kreger, A. S., A. W. Bernheimer, L. A. Etkin, and L. W. Daniel. 1987. Phospholipase D activity of Vibrio damsela cytolysin and its interaction with sheep erythrocytes. Infect. Immun. 55:3209-3212.

14. Lee, K.-K., and A. E. Ellis. 1990. Glycerophospholipid:cholesterol acyltransferase complexed with the lipopolysaccharide (LPS) is a major lethal exotoxin and cytolysin of Aeromonas salmonicida: LPS stabilizes and enhances toxicity of the enzyme. J. Bacteriol. 172:5382-5393.

15. Magariños, B., J. L. Romalde, I. Bandin, B. Fouz, and A. E. Toranzo. 1992. Phenotypic, antigenic, and molecular characterization of Pasteurella piscicida strains isolated from fish. Appl. Environ. Microbiol. 58:3316-3322.

16. Magariños, B., Y. Santos, J. L. Romalde, C. Rivas, J. L. Barja, and A. E. Toranzo. 1992. Pathogenic activities of live cells and extracellular products of the fish pathogen Pasteurella piscicida. J. Gen. Microbiol. 138:2491-2498.

17. Marmur, J. 1961. A procedure for the isolation of deoxyribonucleic acid from micro-organisms. J. Mol. Biol. 3:208-218.

18. Reichelt, J. L., and P. Baumann. 1973. Taxonomy of the marine luminous bacteria. Arch. Microbiol. 94:283-330.

19. Ruimy, R., V. Breittmayer, P. ElBaze, B. Lafay, O. Boussemart, M. Gauthier, and R. Christen. 1994. A general phylogenetic analysis of the family Vibrionaceae (Vibrio, Photobacterium, Aeromonas, Plesiomonas) deduced from the comparison of nearly complete $16 \mathrm{~S}$ rRNA sequences. Int. J. Syst. Bacteriol. 44:416-426.

20. Saitou, N., and M. Nei. 1987. The neighbor-joining method: a new method for reconstructing phylogenetic trees. Mol. Biol. Evol. 4:406-425.

21. Simidu, U., and S. Egusa. 1972. A re-examination of the fish-pathogenic bacterium that had been reported as a Pasteurella species. Bull. Jpn. Soc. Sci. Fish. 38:803-812.

22. Skerman, V. B. D., V. McGowan, and P. H. A. Sneath. 1989. Approved lists of bacterial names, amended edition, p. 72. American Society for Microbiology, Washington, D.C.

23. Smith, S. K., D. C. Sutton, J. A. Fuerst, and J. L. Reichelt. 1991. Evaluation of the genus Listonella and reassignment of Listonella damsela (Love et al.) MacDonell and Colwell to the genus Photobacterium as Photobacterium damsela comb. nov. with an emended description. Int. J. Syst. Bacteriol. 41:529-534. 
24. Snieszko, S. F., G. L. Bullock, E. Hollis, and J. G. Boone. 1964. Pasteurella sp. from an epizootic of white perch (Roccus americanus) in Chesapeake Bay tidewater areas. J. Bacteriol. 88:1814-1815.

25. Sritharan, V., and R. H. Barker. 1991. A simple method for diagnosing $M$. tuberculosis infection in clinical samples using PCR. Mol. Cell. Probes 5:385-395.

26. Stockdale, H., D. W. Ribbons, and E. A. Dawes. 1968. Occurrence of poly- $\beta$-hydroxybutyrate in the Azotobacteriaceae. J. Bacteriol. 95:1798-1803.
27. Swofford, D. 1992. PAUP: phylogenetic analysis using parsimony, version 3.0s. Illinois Natural History Survey, Champaign.

28. Woese, C. R. 1987. Bacterial evolution. Microbiol. Rev. 51:221-271.

29. Zhao, J., and T. Aoki. 1989. A specific DNA hybridization probe for detection of Pasteurella piscicida. Dis. Aquat. Org. 7:203-210.

30. Zhao, J., and T. Aoki. 1992. Plasmid profile analysis of Pasteurella piscicida and use of a plasmid DNA probe to identify the species. J. Aquat. Anim. Health 4:198-202. 